Article

\title{
Bastnaesite, Barite, and Calcite Flotation Behaviors with Salicylhydroxamic Acid as the Collector
}

\author{
Wenliang Xiong ${ }^{1,2}$, Jie Deng ${ }^{2}$, Kaile Zhao ${ }^{2, *}$, Weiqing Wang ${ }^{3, *}$, Yanhong Wang ${ }^{4}$ and \\ Dezhou Wei ${ }^{1}$ \\ 1 College of Resources and Civil Engineering, Northeastern University, Shenyang 110819, China; \\ seanwlzm@163.com (W.X.); dzwei@mail.neu.edu.cn (D.W.) \\ 2 Institute of Multipurpose Utilization of Mineral Resources, Chinese Academy of Geological Sciences, \\ Chengdu 610041, China; dengjie23@126.com \\ 3 School of Environment and Resource, Southwest University of Science and Technology, \\ Mianyang 621010, China \\ 4 School of Minerals Processing and Bio-engineering, Central South University, Changsha 410083, China; \\ yanhong.wang@csu.edu.cn \\ * Correspondence: zhaokaile@csu.edu.cn (K.Z.); wangweiqing@swust.edu.cn (W.W.)
}

Received: 13 February 2020; Accepted: 18 March 2020; Published: 20 March 2020

check for updates

\begin{abstract}
The flotation of bastnaesite, as a major mineral source of rare earth elements, attracting much attention in the mineral processing field, is challenging owing to the natural flotability of calcium-bearing minerals. To promote the application of flotation, we systematically investigated the flotation behavior of bastnaesite, barite, and calcite, with salicylhydroxamic acid (SHA) as the collector through micro-flotation experiments, zeta-potential measurements, Fourier transform infrared (FT-IR) analyses, X-ray photoelectron spectroscopy (XPS) analyses, and solution chemistry analyses. Micro-flotation experiments confirm that the flotability of bastnaesite is high at $\mathrm{pH} 6.5-8.5$, while calcite floats at $\mathrm{pH} 8.0-9.5$, and barite has little flotation response. The results of FT-IR, XPS, and zeta-potential measurements indicate that there is chemical adsorption of SHA on the bastnaesite surface, and physical adsorption also occurs. However, as for barite and calcite, there is only physical adsorption of SHA on the surfaces. The solution chemistry results show that SHA anions can interact with $\mathrm{RE}^{3+}, \mathrm{REOH}^{2+}$, and $\mathrm{RE}(\mathrm{OH})_{2}{ }^{+}$on bastnaesite surfaces in aqueous suspensions, resulting in bastnaesite flotation.
\end{abstract}

Keywords: bastnaesite; barite; calcite; salicylhydroxamic acid; flotation

\section{Introduction}

Rare earth elements (REEs) are a group of 15 elements of the lanthanide series together with Sc and Y. Based on the ionic radii of elements, REEs can be classified into light rare earth elements (LREEs) from $\mathrm{La}$ to $\mathrm{Sm}$, and heavy rare earth elements (HREEs) from $\mathrm{Eu}$ to $\mathrm{Lu}[1,2]$. REEs are crucial to manufacturing of many advanced products and have broad commercial applications, such as new catalysts for automotive exhaust systems, permanent magnets for computer equipment, medical diagnosis equipment, and almost all military systems [3,4]. A semi-soluble salt mineral with the characteristics of ionic bonding and limited solubility in water, bastnaesite, $(\mathrm{Ce}, \mathrm{La}) \mathrm{FCO}_{3}$, is a complex rare earth fluoride and carbonate salt and contains the cerium subgroup or the lighter rare earth elements. Bastnaesite is considered as one of the most important sources of rare earth elements because of its richness in the light rare earth elements and its large global reserves [5]. Bastnaesite deposits are located in the Mountain Pass deposit in San Bernardino County, California (USA), Boyan Obo deposit in Inner Mongolia (China), and Mianning deposit in Mianning, Sichuan (China) [2,6]. 
In China, the Mianning rare earth deposit is an alkaline pegmatite carbonate-type rare earth deposit with total industrial reserve of $1.3 \mathrm{Mt}$ at an average grade of REO $3.7 \mathrm{wt} \%$ [7,8]. Froth flotation is applied for the separation of the bastnaesite ore $[9,10]$. After the raw ore is crushed and ground, the salicylhydroxamic acid or sodium oleate can be used as a collector for separating bastnaesite from associated gangue minerals (calcium-bearing minerals) [11-13]. According to the X-ray diffraction (XRD) pattern of the raw ore collected from the Mianning deposit (Figure 1), the major gangue minerals are barite, calcite, fluorite, and quartz [14]. The calcium-bearing minerals (such as calcite, fluorite) have chemical properties and hydrophilicity, which makes it difficult to separate these minerals [15-18].

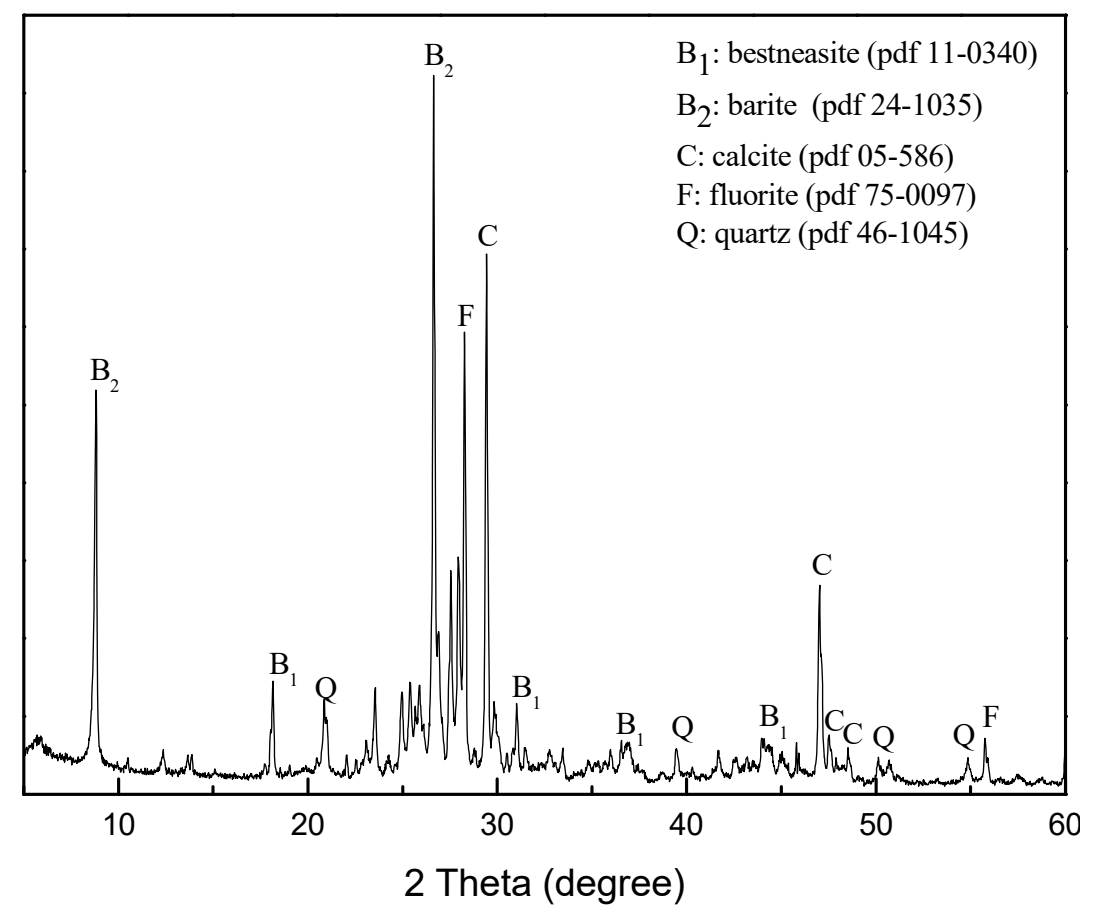

Figure 1. X-ray diffraction (XRD) pattern of the raw ore collected from Mianning deposit in Sichuan province, China.

The flotation reagents play a vital role in the development of rare earth beneficiation technology, and hydroxamate collectors have been successfully applied to the flotation of rare earth minerals because of their high selectivity and strong collective capabilities. The study of the 1-hydroxyl-2-naphthyl hydroxamic acid $\left(\mathrm{H}_{203}\right)$ collector claimed chemical adsorption between oxygen atoms of $\mathrm{H}_{203}$ and rare earth ions, generating five-element chelate rings, and physical adsorption [6,19]. A study of salicylhydroxamic acid collectors suggested the rare earth cation hydrolysis of major surface components of bastnaesite, followed by chemical reaction with salicylhydroxamic to form five elements chelate rings [11]. Electrostatic charge calculationindicated that the alkyl hydroxamic acid, as an $\mathrm{O}-\mathrm{O}$ chelating agent, could form $\mathrm{O}-\mathrm{O}$ five elements chelate ring with metallic ions, and it is also $\mathrm{O}-\mathrm{N}$ chelating agent, which can form O-N four elements chelate ring with metallic ions [20-23]. This mechanism shows that chemical adsorption takes place between bastnaesite and octylhydroxamic, with five elements chelate rings forming on the surface of bastnaesite [3,17,24-28].

To our best knowledge, although the flotation behaviors of bastnaesite using salicylhydroxamic acid (SHA) as the collector has been researched, it is also important to further research the flotation behaviors of the main gangue minerals, such as barite and calcite. The results of this paper are of practical significance for understanding and grasping the flotation nature of valuable minerals and gangue minerals in bastnaesite ores and guiding the development and utilization of rare earth deposits. 


\section{Experimental}

\subsection{Materials}

The samples of bastnaesite, barite, and calcite were obtained from the Maoniuping rare earth concentrator, located in Mianning, Sichuan province, China. After manual selection, ginding, sieving, the repeated purification by using gravity and magnetic separation, purified bastnaesite, barite, and calcite samples were obtained. These were dry-ground in a ball mill. Subsequently, powder sample of $-0.10 \mathrm{~mm}$ fractions was used in the micro-flotation tests.

The chemical composition of the purified bastnaesite is listed in Table 1. The results show the REO content is $72.52 \mathrm{wt} \%$, and the main rare earth elements are $\mathrm{Ce}, \mathrm{La}$, and $\mathrm{Nd}$. The content of the other impurity element is very low. The diffraction peaks of the XRD pattern $[29,30]$ was well matched with the standard diffraction peaks of bastnaesite (pdf: 11-0340). The chemical composition and XRD analyses indicate that the purity of the purified bastnaesite was high, and the sample was suitable for the experiments.

Table 1. Chemical compositions of the purified bastnaesite (mass fraction, wt \%).

\begin{tabular}{lccccccccc}
\hline Element & $\mathrm{REO}$ & $\mathrm{CeO}_{2}$ & $\mathrm{La}_{2} \mathrm{O}_{3}$ & $\mathrm{Nd}_{2} \mathrm{O}_{3}$ & $\mathrm{Pr}_{6} \mathrm{O}_{11}$ & $\mathrm{Sm}_{2} \mathrm{O}_{3}$ & $\mathrm{Gd}_{2} \mathrm{O}_{3}$ & $\mathrm{Eu}_{2} \mathrm{O}_{3}$ & $\mathrm{Dy}_{2} \mathrm{O}_{3}$ \\
Content & 72.52 & 35.55 & 25.43 & 7.33 & 3.22 & 0.59 & 0.17 & 0.08 & 0.06 \\
\hline Element & $\mathrm{Y}_{2} \mathbf{O}_{3}$ & $\mathrm{~Tb}_{4} \mathbf{O}_{7}$ & $\mathbf{F}$ & $\mathrm{SiO}_{2}$ & $\mathrm{Al}_{2} \mathbf{O}_{3}$ & $\mathrm{Fe}_{2} \mathbf{O}_{3}$ & $\mathrm{TiO}_{2}$ & $\mathrm{CaO}$ & $\mathrm{LOI}$ \\
Content & 0.05 & 0.04 & 6.68 & 0.36 & 0.22 & 1.43 & 0.09 & 0.16 & 19.90 \\
\hline
\end{tabular}

The $\mathrm{BaO}$ content of the purified barite was $64.66 \mathrm{wt} \%$. The $\mathrm{CaO}$ content of the purified calcite was $55.88 \mathrm{wt} \%$. According to the theoretical element composition of each mineral, the sample purities exceed $95 \mathrm{wt} \%$. The diffraction peaks of the barite, and calcite matched well with the pattern of standard diffractions peaks (barite pdf 24-1035; calcite pdf 05-0586). The XRD analysis confirm that the purities of the gangue minerals was sufficient for further experimentation.

\subsection{Reagents}

The salicylhydroxamic acid (SHA, $\mathrm{HOC}_{6} \mathrm{H}_{4} \mathrm{CONHOH}$, purity $95 \mathrm{wt} \%$ ) was obtained from Aladdin Chemical Reagent Co. (Shanghai, China) and was used as the collector for flotation experiments. Sulfuric acid $\left(\mathrm{H}_{2} \mathrm{SO}_{4}\right)$ and sodium hydroxide $(\mathrm{NaOH})$ were of analytical grade and used to adjust the $\mathrm{pH}$ of the flotation suspensions. The pine oil of industrial grade was used as the frother. The water used for all the experiments was deionized water with resistivity of $18.25 \mathrm{M} \Omega \cdot \mathrm{cm}$ [31].

\subsection{Micro-Flotation Experiments}

Micro-flotation experiments were carried out in an XFG- $40 \mathrm{~mL}$ type flotation machine. The purified mineral particles $(2.0 \mathrm{~g})$ were placed in a Plexiglas cell, which was then filled with $35 \mathrm{~mL}$ of deionized water, the $\mathrm{pH}$ of the suspension was adjusted by $\mathrm{H}_{2} \mathrm{SO}_{4}$ or $\mathrm{NaOH}$ for $3 \mathrm{~min}$. Subsequently, SHA collector was added and agitated for $3 \mathrm{~min}$. The foaming agent (pine oil) was added and agitated for $1 \mathrm{~min}$. Before flotation, the $\mathrm{pH}$ of the suspension was measured and recorded. Flotation was conducted for $4 \mathrm{~min}$. The flotation product was weighed after filtering and drying, and the recoveries were calculated based on the dry weight. Three measurements of each micro-flotation experiment were carried out, and the average value was taken as the result.

\subsection{Zeta-Potential Measurements}

The zeta-potential was measured using a Zetasizer Nano Zs90 (Malvern Instruments, Worcestershire, $\mathrm{UK})$. The conductivity and $\mathrm{pH}$ of the suspension were monitored continuously during the measurement, and the temperature was maintained at $25^{\circ} \mathrm{C}$. The purified mineral particles were ground to $<2 \mu \mathrm{m}$ using an agate mortar. The suspension was prepared by adding $30 \mathrm{mg}$ of the purified mineral particles 
to $50 \mathrm{~mL}$ deionized water. The prepared suspension was conditioned by magnetically stirring for $5 \mathrm{~min}$, during which the $\mathrm{pH}$ of the suspension was measured. After settling for $10 \mathrm{~min}$, the supernatant of the dilute fine particle suspension was obtained for zeta-potential measurements. The zeta potential was measured three times and the average value was taken as the final result.

\subsection{FT-IR Spectroscopy Measurements}

FT-IR spectra were measured using a Spectrum One FT-IR (PerkinElmer, Waltham, MA, USA) spectrometer to characterize the interaction between the collector and minerals. The wave number range of the spectra was 4000 to $400 \mathrm{~cm}^{-1}$. The purified mineral particles were first ground to $-200 \mathrm{mesh}$ using an agate mortar. The purified mineral particles $(2.0 \mathrm{~g})$ were placed in a Plexiglas cell. After the $\mathrm{pH}$ of the suspension was adjusted to 7.5, the purified samples were conditioned for another 3 min with $2 \times 10^{-4} \mathrm{M}$ SHA. Subsequently, the solid samples were washed three times using ultrapure water with the same $\mathrm{pH}$ value. The washed samples for FT-IR analysis were dried at $35^{\circ} \mathrm{C}$.

\subsection{XPS Analysis}

Total of $2.0 \mathrm{~g}$ purified mineral particles were placed in a Plexiglas cell with $\mathrm{H}_{2} \mathrm{SO}_{4}$ or $\mathrm{NaOH}$ as the pH-regulating reagent. Subsequently, the purified samples were conditioned for another 3 min with SHA. The solid samples were washed three times using deionized water. Then the samples for XPS analysis were vacuum-dried at $50^{\circ} \mathrm{C}$. XPS analyses were performed by a Kratos AXIS Ultra XPS system (Shimadzu, Kyoto, Japan), which was equipped with a monochromatic Al X-ray source operated at $150 \mathrm{~W}$. The energy resolution is $0.48 \mathrm{eV}\left(\mathrm{Ag} \mathrm{3d_{5/2 }}\right)$ with error of $0.05 \mathrm{eV}$. Survey scans were conducted in a single sweep from 0 to $1350 \mathrm{eV}$, with a dwell time of $8 \mathrm{~s}$, pass energy of $150 \mathrm{eV}$, and $1 \mathrm{eV}$ step size. For high-resolution scanning, the number of scans was increased, the dwell time was reduced to $0.5 \mathrm{~s}$, and the bandpass energy was adjusted to $30 \mathrm{eV}$ in steps of $50 \mathrm{meV}$. The purified mineral particles $(2.0 \mathrm{~g})$ were placed in a Plexiglas cell. Subsequently, the purified samples were conditioned for another 3 min with SHA. The solid samples were washed three times using deionized water. The washed samples for XPS analysis were vacuum-dried at $50{ }^{\circ} \mathrm{C}$.

\section{Results}

\subsection{Micro-Flotation Tests}

Figure 2 shows the flotation recoveries of bastnaesite, barite, and calcite as a function of $\mathrm{pH}$ using SHA as the collector $\left(2 \times 10^{-4} \mathrm{M}\right)$, pine oil as the frother $\left(14 \mathrm{mg} \cdot \mathrm{L}^{-1}\right)$. The results show that the flotability of bastnaesite is better than that of barite or calcite at $\mathrm{pH}$ 5.5-9.5. The flotability of bastnaesite reaches its maximum at $\mathrm{pH}$ 6.5-8.5, while calcite floating at $\mathrm{pH} \mathrm{8.0-9.5,} \mathrm{but} \mathrm{barite,} \mathrm{showing} \mathrm{little}$ flotation response, is almost unaffected with $\mathrm{pH}$ value.

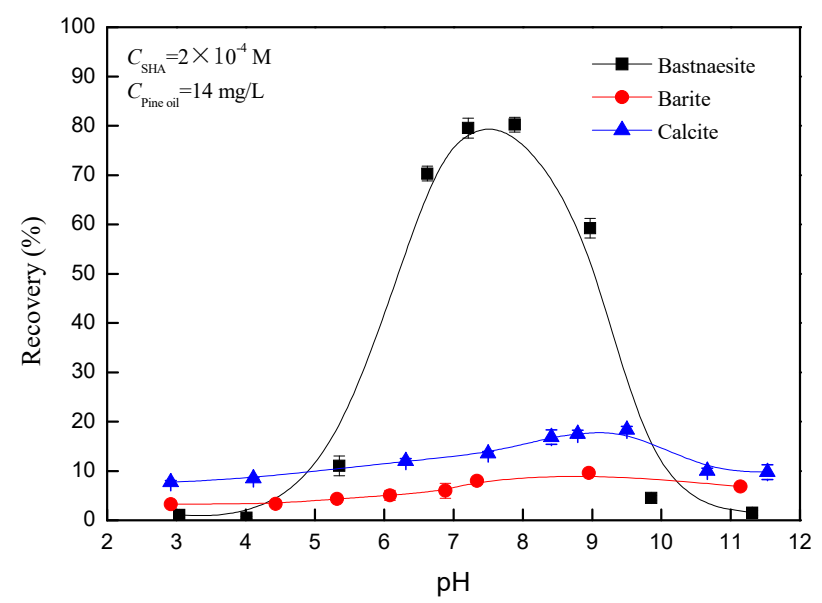

Figure 2. Flotation recoveries of the minerals as a function of $\mathrm{pH}$. 
Figure 3 shows the relationship between SHA concentrations and the flotation recoveries of bastnaesite, barite, and calcite at $\mathrm{pH}$ 7.5. The flotation recovery of bastnaesite rises with the increasing SHA concentration. Compared to the apparently increased trend of bastnaesite recovery, the flotation recoveries of barite, and calcite grow slowly with increasing SHA concentration.

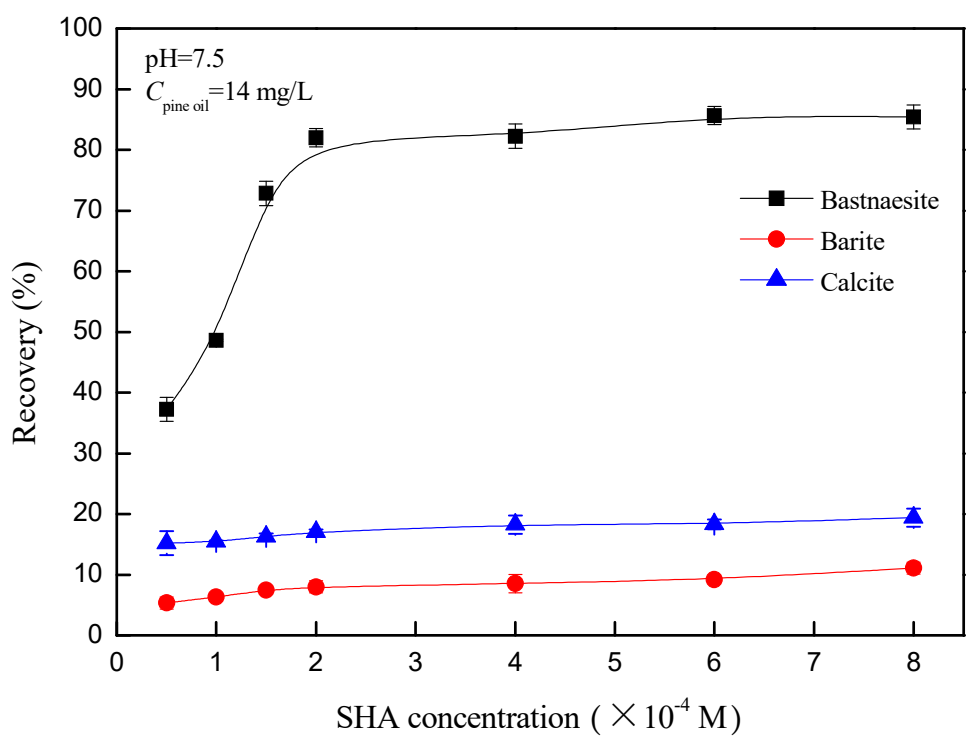

Figure 3. Flotation recoveries as a function of salicylhydroxamic acid (SHA) concentration.

\subsection{Zeta-Potential Tests}

Figure 4 shows the zeta-potentials of bastnaesite, barite, and calcite in the absence and presence of SHA as a function of $\mathrm{pH}$. In the absence of SHA, the results show that the isoelectric points (IEP) of bastnaesite, and barite are at $\mathrm{pH} 8.1$ and 8.3, respectively. The IEP of calcite may be located around pH 8.0 [32,33]. In the presence of SHA, the zeta-potentials of bastnaesite, barite, and calcite are all negative at $\mathrm{pH}$ 5.0-12.0. Compared with barite and calcite, the significant decrease in zeta-potential of bastnaesite can be attributed to the grater adsorbed amount of SHA ions onto the bastnaesite surface indicating that SHA may more selectively interact with the bastnaesite surface than on the barite and calcite surfaces.

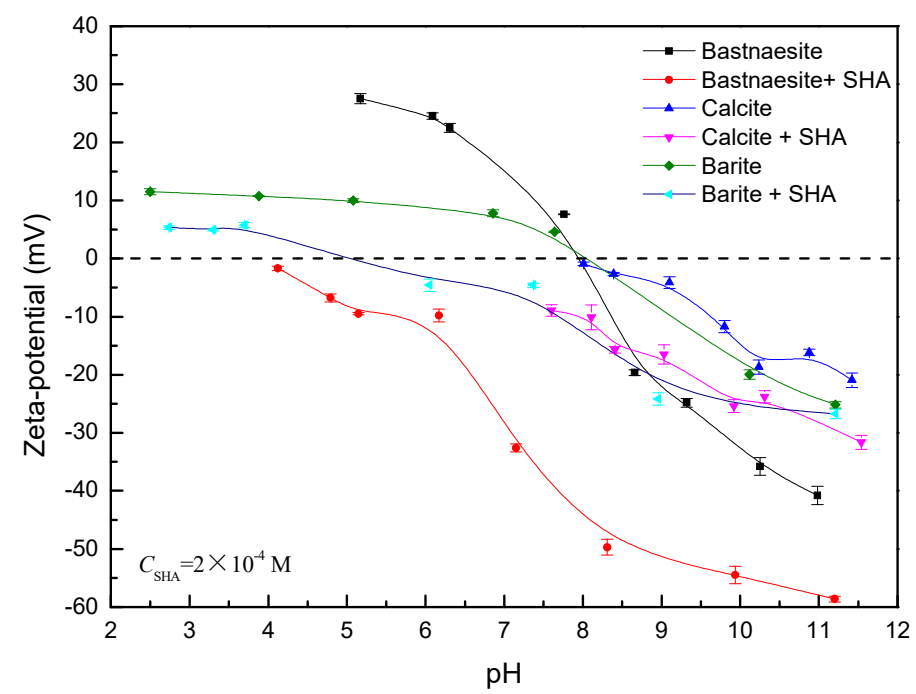

Figure 4. Zeta-potential of bastnaesite, calcite, and bariteas a function of $\mathrm{pH}$ in the absence and presence of SHA. 


\subsection{FT-IR Analysis}

Figure 5 a shows the FT-IR spectra of SHA, bastnaesite, barite, and calcite. Figure $5 \mathrm{~b}$ shows the FT-IR spectra of the bastnaesite, barite, and calcite with $2 \times 10^{-4} \mathrm{MSHA}$. The main bands corresponding to the relevant chemical bond is displayed in Table 2. Several characteristic bands of bastnaesite were observed. Characteristic bands of barite, calcite were aslo observed [34,35]. After the bastnaesite treated with SHA, the characteristic band of $\mathrm{CO}_{3}{ }^{2-}$ anti-symmetric stretching vibration is at $1436 \mathrm{~cm}^{-1}$, off set $10 \mathrm{~cm}^{-1}$, and other bands shift to the higher frequencies. In addition, the band at $1035 \mathrm{~cm}^{-1}$ and $912 \mathrm{~cm}^{-1}$ belong to the $\mathrm{N}-\mathrm{O}$ stretching vibration adsorption peak, while the characteristic peak of the $\mathrm{N}-\mathrm{O}$ stretching vibration in SHA is at $1031 \mathrm{~cm}^{-1}$ and $903 \mathrm{~cm}^{-1}$. These two bands were characteristic of adsorption peaks of SHA, indicating chemical adsorption of the SHA onto the surface of bastnaesite. But there were no characteristic adsorption peaks of SHA on barite or calcite.
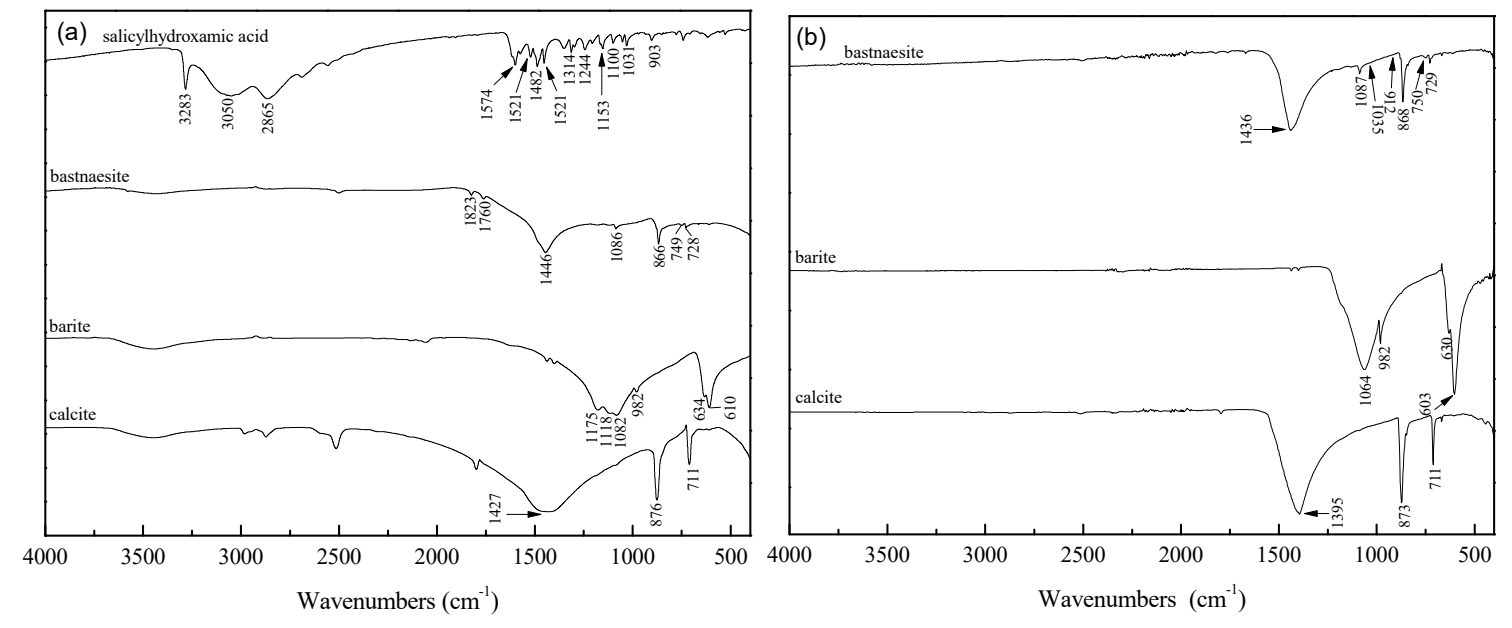

Figure 5. Fourier transform infrared (FT-IR) spectra of purified samples before (a) and after (b) treated with SHA at $\mathrm{pH} 7.5$.

Table 2. The bands corresponding to the relevant chemical bond in FT-IR spectra of the minerals.

\begin{tabular}{|c|c|c|}
\hline FTIR Spectrum & Band $\left(\mathrm{cm}^{-1}\right)$ & Chemical Bond \\
\hline \multirow{7}{*}{ SHA } & 3283 & O-H stretching vibration \\
\hline & 3050 & $-\mathrm{CH}_{3}$ stretching vibration \\
\hline & 1574 & $\mathrm{C}=\mathrm{O}$ stretching vibration \\
\hline & 1521 & $\mathrm{C}-\mathrm{C}$ stretch vibration \\
\hline & 1153 & C-O stretching vibration \\
\hline & 1031 & $\mathrm{~N}-\mathrm{O}$ stretch vibration \\
\hline & 903 & $\mathrm{~N}-\mathrm{O}$ stretching vibration \\
\hline \multirow{4}{*}{ Bastnaesite } & 1446 & $\mathrm{CO}_{3}{ }^{2-}$ anti-symmetric stretching vibration \\
\hline & 1086 & $\mathrm{CO}_{3}^{2-}$ symmetric stretching vibration \\
\hline & 866 & $\mathrm{CO}_{3}{ }^{2-}$ plane bending vibration \\
\hline & 728 & $\mathrm{CO}_{3}^{2-}$ in-plane bending vibration \\
\hline \multirow{6}{*}{ Bastnaesite + SHA } & 1436 & $\mathrm{CO}_{3}{ }^{2-}$ anti-symmetric stretching vibration \\
\hline & 1087 & $\mathrm{CO}_{3}{ }^{2-}$ symmetric stretching vibration \\
\hline & 1035 & N-O stretch vibration \\
\hline & 912 & $\mathrm{~N}-\mathrm{O}$ stretching vibration \\
\hline & 868 & $\mathrm{CO}_{3}{ }^{2-}$ plane bending vibration \\
\hline & 729 & $\mathrm{CO}_{3}^{2-}$ in-plane bending vibration \\
\hline
\end{tabular}

As can be seen in Figures 2-5, the decrease in the zeta-potential of bastnaesite on SHA adsorption was more than that of barite and calcite, and the flotability of bastnaesite was much better than that of 
barite or calcite. These observations indicate that the adsorption of SHA with bastnaesite is stronger than with barite and calcite. It is concluded that the interaction of SHA with the surface of bastnaesite occurs by chemical adsorption, while the surfaces of barite and calcite interact with SHA through physical adsorption.

\subsection{Solution Chemistry Analysis}

The solution chemistry of SHA and metallic ion can be calculated to obtain the concentration log diagram of each component at different $\mathrm{pH}$ [36]. Figure 6 shows the pulp SHA and metallic ions exist in different forms at different $\mathrm{pH}$. The forms of SHA and metallic ions can affect the flotation behaviors of the minerals.
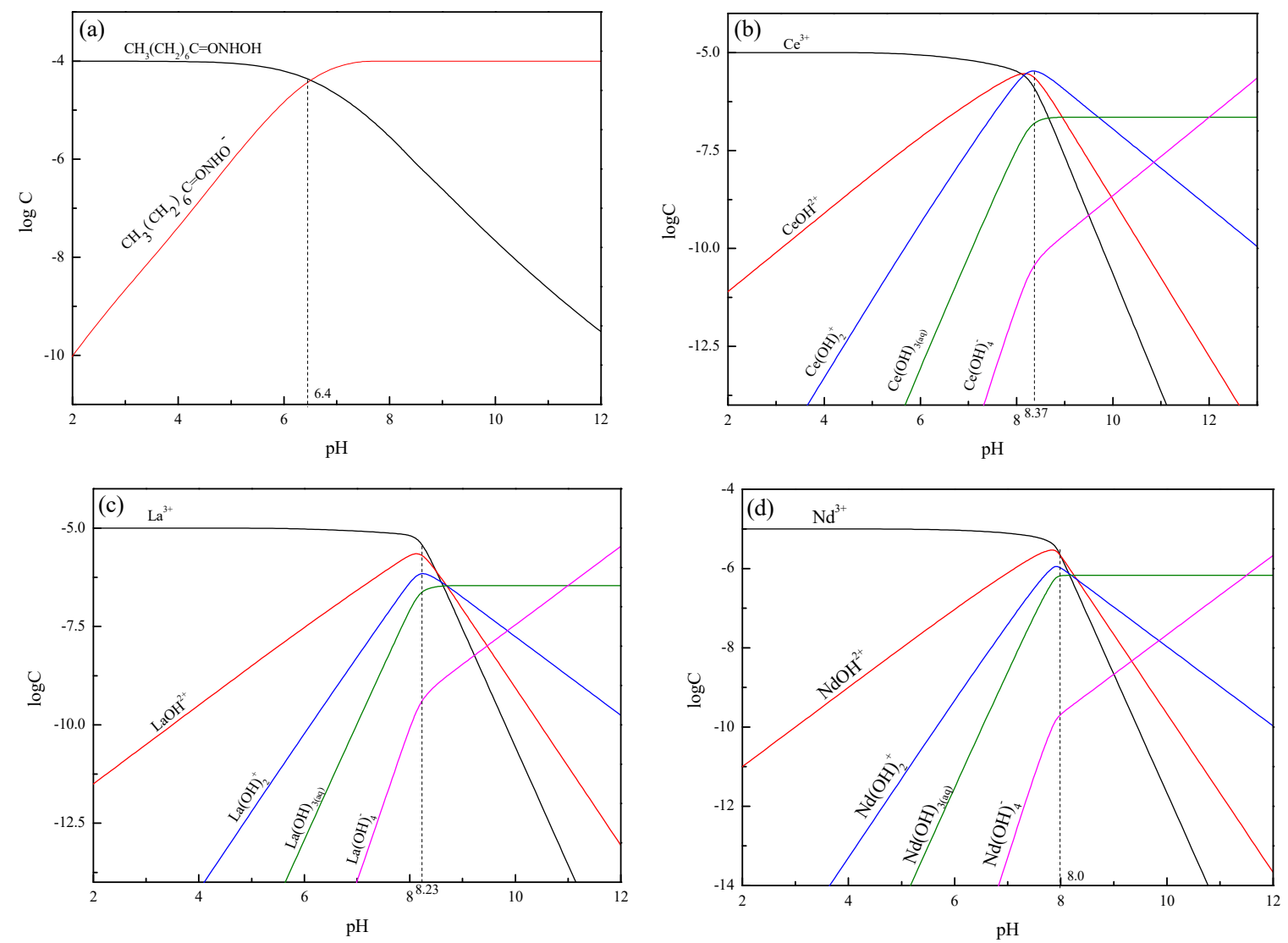

Figure 6. Logarithmic diagram of (a) SHA $\left(C=2 \times 10^{-4} \mathrm{M}\right)$, (b) cerium $\left(C=2 \times 10^{-4} \mathrm{M}\right)$, (c) lanthanum $\left(C=2 \times 10^{-4} \mathrm{M}\right)$, and $(\mathrm{d})$ neodymium $\left(\mathrm{C}=2 \times 10^{-4} \mathrm{M}\right)$.

Figure 6a shows the SHA hydrolysis components as a function of $\mathrm{pH}$ for SHA concentration of $2 \times 10^{-4} \mathrm{M}$. The $\mathrm{pKa}$ of SHA was found to be 6.4. When the $\mathrm{pH}$ was less than 6.4 , the main component present is $\mathrm{CH}_{3}\left(\mathrm{CH}_{2}\right)_{6} \mathrm{C}=\mathrm{ONHOH}$. When $\mathrm{pH}$ was more than 6.4 , the main component is $\mathrm{CH}_{3}\left(\mathrm{CH}_{2}\right)_{6} \mathrm{C}=\mathrm{ONHO}^{-}$. Figure $6 \mathrm{~b}-\mathrm{d}$ show the hydrolysis components of bastnaesite with as a function of $\mathrm{pH}$ with metallic ion concentration of $2 \times 10^{-4} \mathrm{M}$. The $\mathrm{pKa}$ of cerium, lanthanum, and neodymium was found to be $8.37,8.23$, and 8.0, respectively. When $\mathrm{pH}$ was less than 8.0, the components are $\mathrm{RE}^{3+}$ $>\mathrm{REOH}^{2+}>\mathrm{RE}(\mathrm{OH})_{2}{ }^{+}>\mathrm{RE}(\mathrm{OH})_{3 \text { (aq.) }}>\mathrm{RE}(\mathrm{OH})_{4}{ }^{-}$. These observations indicate that the hydrolysis components $\left(\mathrm{CH}_{3}\left(\mathrm{CH}_{2}\right)_{6} \mathrm{C}=\mathrm{ONHO}^{-}\right)$can interact with metallic ions $\left(\mathrm{RE}^{3+}, \mathrm{REOH}^{2+}\right.$, and $\left.\mathrm{RE}(\mathrm{OH})_{2}{ }^{+}\right)$ on bastnaesite surfaces at $\mathrm{pH}$ 6.4-8.4. The interactions result in the flotation behavior of bastnaesite (Figure 2). 


\subsection{XPS Analysis}

To further determine the interaction mechanism between SHA and the minerals, XPS analyses were conducted. The relative contents of the elements on the surface of the minerals in the absence and presence of SHA, as measured by XPS, are listed in Table 3. The N content can be taken to represent the amount of SHA adsorbed on the mineral surface. After bastnaesite was treated with SHA, the relative content of $\mathrm{N}$ reached $1.51 \mathrm{at} \%$. However, on the surface of barite and calcite treated by SHA the relative contents of $\mathrm{N}$ were only 0.88 at $\%$, and $0.53 \mathrm{at} \%$, respectively. This result indicates that the adsorption of SHA on bastnaesite and barite are stronger than the adsorption onto calcite. This is in accordance with the results of micro-flotation, zeta-potential, FT-IR, and solution chemistry measurements.

Table 3. Elemental compositions of minerals surfaces, as determined via X-ray photoelectron spectroscopy (XPS).

\begin{tabular}{ccccccccccc}
\hline \multirow{2}{*}{ Samples } & \multicolumn{10}{c}{ Elemental Composition (at\%) } \\
\cline { 2 - 11 } & $\mathbf{C}$ & $\mathbf{O}$ & $\mathbf{F}$ & $\mathbf{C a}$ & $\mathbf{N}$ & $\mathbf{S}$ & $\mathbf{B a}$ & $\mathbf{N d}$ & $\mathbf{L a}$ & $\mathbf{C e}$ \\
\hline Bastnaesite & 42.93 & 41.66 & 8.79 & 0.00 & 0.00 & 0.00 & 0.00 & 1.57 & 2.43 & 2.62 \\
Bastnaesite + SHA & 46.50 & 38.47 & 7.74 & 0.00 & 1.51 & 0.00 & 0.00 & 1.28 & 2.19 & 2.31 \\
Barite & 28.90 & 47.55 & 0.00 & 0.00 & 0.00 & 13.45 & 10.10 & 0.00 & 0.00 & 0.00 \\
Barite + SHA & 30.52 & 47.09 & 0.00 & 0.00 & 0.88 & 13.22 & 8.29 & 0.00 & 0.00 & 0.00 \\
Calcite & 46.05 & 40.31 & 0.00 & 13.64 & 0.00 & 0.00 & 0.00 & 0.00 & 0.00 & 0.00 \\
Calcite + SHA & 47.81 & 38.96 & 0.00 & 12.70 & 0.53 & 0.00 & 0.00 & 0.00 & 0.00 & 0.00 \\
\hline
\end{tabular}

Table 4 shows the binding energies of the main elements on the mineral surface before and after the treatments with SHA. After SHA treatment, the chemical shifts of $\mathrm{Ce}, \mathrm{La}$, and $\mathrm{Nd}$ in bastnaesite were obvious being $-0.35 \mathrm{eV},-0.38 \mathrm{eV}$, and $-0.74 \mathrm{eV}$, respectively. This indicates the transformation of the chemical environment on the bastnaesite surface and that the SHA was chemisorbed on the surface of bastnaesite. Upon treatment of barite and calcite by SHA, chemical shifts were not obvious, indicating the transformation of the physical environment on these mineral surfaces. This result indicates that SHA probably adsorbs on the surface of these minerals through physical interaction.

Table 4. Binding energies of elements on the minerals surface, as determined via XPS.

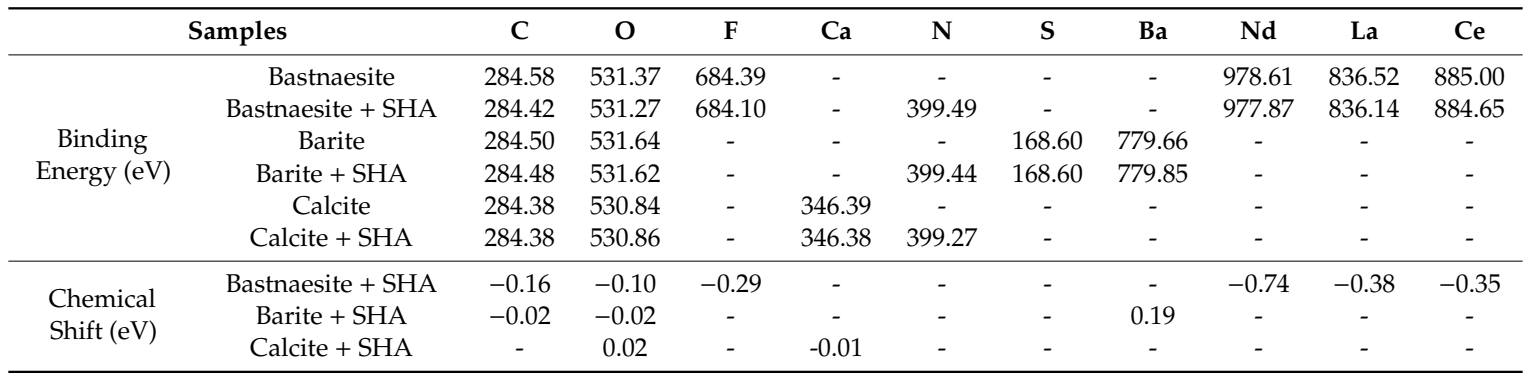

\subsection{Discussion}

According to the experimental results and analyses, SHA can be chemisorbed on the bastnaesite surface resulting in enhanced flotability; the interaction between SHA and barite and calcite is mainly by physical adsorption. The previous works of Rao and Wang also reported that the chemisorption occurred between bastnaesite and salicylhydroximic acid, octyl hydroximic acid, modified alkyl hydroximic acid or sodium oleate, while physisorption occurred between sodium dodecyl sulfate and bastnaesite [11,37].

The results of the micro-flotation tests indicate that the flotability of bastnaesite is better than that of barite and calcite across a wide $\mathrm{pH}$ range. The zeta-potential analysis shows that adsorption of SHA on the bastnaesite, barite, and calcite surfaces can occur. The zeta potential of bastnaesite decreased 
most obviously on SHA adsorption, consistent with the results of the micro-flotation tests. The FT-IR results give further evidence that SHA can chemisorb onto the surface of bastnaesite, but is physically adsorbed onto the surfaces of barite and calcite. The solution chemistry results show that SHA anions $\left(\mathrm{CH}_{3}\left(\mathrm{CH}_{2}\right)_{6} \mathrm{C}=\mathrm{ONHO}^{-}\right)$can interact with $\mathrm{RE}^{3+}, \mathrm{REOH}^{2+}$, and $\mathrm{RE}(\mathrm{OH})_{2}{ }^{+}$on bastnaesite surfaces at pH 6.4-8.4, resulting in bastnaesite flotation. XPS analysis shows that the RE electronically interacts with SHA on the surface of the bastnaesite. After bastnaesite was treated by SHA, the chemical shifts of $\mathrm{Ce}, \mathrm{La}$, and $\mathrm{Nd}$ were $-0.35 \mathrm{eV},-0.38 \mathrm{eV}$, and $-0.74 \mathrm{eV}$, respectively. After barite and calcite were treated by SHA chemical shifts of the main element of these minerals were not obvious, hence, no transformation of the electronic environment on these mineral surfaces was observed. The shifts in RE of XPS provide evidence of electronic perturbation which may be due to the changes in chemical bonding, consistent with the results of the zeta-potential, solution chemistry, and FT-IR.

Based on the results of the FT-IR and XPS analyses, it is concluded that RE can chemically interact with SHA to promote bastnaesite flotation. Barite and calcite react with SHA via physical interaction. It can be considered that this is the reason for the significantly better flotability of bastnaesite than barite and calcite.

\section{Conclusions}

(1) The results of micro-flotation experiments using SHA as the collector molecule indicate that bastnaesite exhibits good flotability around $\mathrm{pH}$ 6.5-8.5. Calcite possesses low flotability at $\mathrm{pH}$ 8.0-9.5. Barite has little flotation response across the whole $\mathrm{pH}$ range used in the experiments.

(2) The decrease in the zeta-potential of bastnaesite, barite, and calcite can be attributed to the adsorption of SHA anions. SHA can more selectively interact with the bastnaesite surface than the barite and calcite surface.

(3) The FT-IR, XPS, and solution chemistry results indicate that SHA anions can react with $\mathrm{RE}^{3+}$, $\mathrm{REOH}^{2+}$, and $\mathrm{RE}(\mathrm{OH})_{2}{ }^{+}$on the surface of bastnaesite, and SHA molecule may be chemically adsorbed on the surface. The adsorption between SHA and barite or calcite may be physical. This is the reason for the significantly better flotability of bastnaesite than barite and calcite.

Author Contributions: W.X., D.W. conceived and designed the experiments; W.W., J.D., and K.Z. performed the experiments and analyzed the data; W.W., Y.W., and K.Z. wrote and revised the paper. All authors have read and agreed to the published version of the manuscript.

Funding: This research was funded by the Youth Talent Project of China Ministry of Natural Resources, grant number B1901, and the Program of China Geological Survey, grant numbers DD20174922, 121201016000150002.

Conflicts of Interest: The authors declare no conflict of interest.

\section{References}

1. Kumari, A.; Panda, R.; Jha, M.K.; Kumar, J.R.; Lee, J.Y. Process development to recover rare earth metals from monazite mineral: A review. Miner. Eng. 2015, 79, 102-115. [CrossRef]

2. Xiong, W.; Deng, J.; Chen, B.; Deng, S.; Wei, D. Flotation-magnetic separation for the beneficiation of rare earth ores. Miner. Eng. 2018, 119, 49-56. [CrossRef]

3. Zhang, X.; Du, H.; Wang, X.; Miller, J.D. Surface chemistry aspects of bastnaesite flotation with octylhydroxamate. Int. J. Miner. Process. 2014, 133, 29-38. [CrossRef]

4. Golev, A.; Scott, M.; Erskine, P.D.; Ali, S.H.; Ballantyne, G.R. Rare earths supply chains: Current status, constraints and opportunities. Resour. Policy 2014, 41, 52-59. [CrossRef]

5. Zhou, F.; Wang, L.; Xu, Z.; Liu, Q.; Deng, M.; Chi, R. Application of reactive oily bubbles to bastnaesite flotation. Miner. Eng. 2014, 64, 139-145. [CrossRef]

6. Jordens, A.; Cheng, Y.P.; Waters, K.E. A review of the beneficiation of rare earth element bearing minerals. Miner. Eng. 2013, 41, 97-114. [CrossRef]

7. Li, L.Z.; Yang, X. Chapter 9-China's Rare Earth Resources, Mineralogy, and Beneficiation A2-Lima, Ismar Borges De. In Rare Earths Industry; Filho, W.L., Ed.; Elsevier: Boston, CA, USA, 2016; pp. 139-150. 
8. Liu, Y.; Chakhmouradian, A.R.; Hou, Z.; Song, W.; Kynický, J. Development of REE mineralization in the giant Maoniuping deposit (Sichuan, China): Insights from mineralogy, fluid inclusions, and trace-element geochemistry. Miner. Depos. 2018, 54, 701-718. [CrossRef]

9. Xia, L.; Brian, H.; Kyle, D. The role of citric acid in the flotation separation of rare earth from the silicates. Miner. Eng. 2015, 74, 123-129. [CrossRef]

10. Cao, Z.; Cao, Y.; Qu, Q.; Zhang, J.; Mu, Y. Separation of bastnäsite from fluorite using ethylenediamine tetraacetic acid as depressant. Miner. Eng. 2019, 134, 134-141. [CrossRef]

11. Wang, C.; Qiu, X.; Hu, Z.; Wang, T.; Li, H. Flotation mechanism of bastnaesite by saliclhydroxamic acid. J. Chin. Soc. Rare Earths 2014, 32, 728.

12. Wang, Z.; Wu, H.; Xu, Y.; Shu, K.; Fang, S.; Xu, L. The effect of dissolved calcite species on the flotation of bastnaesite using sodium oleate. Miner. Eng. 2020, 145, 106095. [CrossRef]

13. Qiu, X.; He, X.; Rao, J.; Yuhe, T.; Luo, C.; Zhang, J. Flotation mechanism of sodium oleate on bastnaesite. Chin. J. Rare Met. 2013, 37, 422-427.

14. Liu, Y.; Hou, Z. A synthesis of mineralization styles with an integrated genetic model of carbonatite-syenite-hosted REE deposits in the Cenozoic Mianning-Dechang REE metallogenic belt, the eastern Tibetan Plateau, southwestern China. J. Asian Earth Sci. 2017, 137, 35-79. [CrossRef]

15. Zhang, X.; Du, H.; Wang, X.; Miller, J.D. Surface chemistry considerations in the flotation of rare-earth and other semisoluble salt minerals. Miner. Met. Explor. 2013, 30, 24-37. [CrossRef]

16. Kupka, N.; Rudolph, M. Froth flotation of scheelite-A review. Int. J. Min. Sci. Technol. 2018, $28,373-384$. [CrossRef]

17. Fuerstenau, D.W. The adsorption of hydroxamate on semi-soluble minerals. Part I: Adsorption on barite, Calcite and Bastnaesite. Colloids Surf. 1983, 8, 103-119.

18. Fuerstenau, D.W.; Herrera-Urbina, R. The surface chemistry of bastnaesite, barite and calcite in aqueous carbonate solutions. Colloids Surf. 1992, 68, 95-102. [CrossRef]

19. Ren, J.; Lu, S.C.; Chi, R.A. Flotation mechanism of bastnaesite with 1-hydroxy-2-napthyl hydroxamic acid. Chin. J. Nonferrous Met. 1996, 7, 24.

20. Zhu, Y.S.; Zhu, J.G. Chemistry Mechanism of Flotation Reagent; Central South University of Industry Press: Changsha, China, 1996; pp. 117-129.

21. Liu, W.; McDonald, L.W., IV; Wang, X.; Miller, J.D. Bastnaesite flotation chemistry issues associated with alkyl phosphate collectors. Miner. Eng. 2018, 127, 286-295. [CrossRef]

22. Liu, W.; Wang, X.; Wang, Z.; Miller, J.D. Flotation chemistry features in bastnaesite flotation with potassium lauryl phosphate. Miner. Eng. 2016, 85, 17-22. [CrossRef]

23. Ren, J. Flotation behaviour and mechanism of bastnaesite with N-hydroxyl phthalicimide. Acta Metall. Sinica (China) (People's Repub. China) 1993, 12, 37-41.

24. Lin, Y.; Chen, C.; Wang, W.; Jiang, Y.; Cao, X. Beneficial effects and mechanism of lead ions for bastnaesite flotation with octylhydroxamic acid collector. Min. Eng. 2020, 148, 106199. [CrossRef]

25. Fuerstenau, D.W. The role of inorganic and organic reagents in the flotation separation of rare-earth ores. Int. J. Miner. Process. 1991, 32, 1-22.

26. Zhiren, Y.; Xue, B.; Wenyuan, W.U. Flotation performance and adsorption mechanism of styrene phosphonic acid as a collector to synthetic $(\mathrm{Ce}, \mathrm{La})_{2} \mathrm{O}_{3}$. J. Rare Earths 2017, 35, 621-628.

27. Rao, J.S.; He, X.J.; Luo, C.S. Flotation Mechanism of OctylHydroxamic Acid on Bastnaesite. J. Chin. Soc. Rare Earths 2015, 33, 370.

28. Li, M.; Gao, K.; Zhang, D.; Duan, H.; Ma, L.; Huang, L. The influence of temperature on rare earth flotation with naphthylhydroxamic acid. J. Rare Earths 2018, 36, 99-107. [CrossRef]

29. Zhang, Y.; Zhao, H.; Zhang, Y.; Liu, H.; Yin, H.; Deng, J.; Qiu, G. Interaction mechanism between marmatite and chalcocite in acidic (microbial) environments. Hydrometallurgy 2020, 191, 105217. [CrossRef]

30. Zhang, X.; Ye, X.; Chen, L.; Zhao, H.; Shi, Q.; Xiao, Y.; Yang, F. Functional role of bloom-forming cyanobacterium Planktothrix in ecologically shaping aquatic environments. Sci. Total Environ. 2020, 710, 136314. [CrossRef]

31. Tian, M.; Gao, Z.; Khoso, S.A.; Sun, W.; Hu, Y. Understanding the activation mechanism of $\mathrm{Pb}^{2+}$ ion in benzohydroxamic acid flotation of spodumene: Experimental findings and DFT simulations. Miner. Eng. 2019, 143, 106006. [CrossRef] 
32. Gao, Z.; Gao, Y.; Zhu, Y.; Hu, Y.; Sun, W. Selective flotation of calcite from fluorite: A novel reagent schedule. Minerals 2016, 6, 114. [CrossRef]

33. Gao, Z.; Bai, D.; Sun, W.; Cao, X.; Hu, Y. Selective flotation of scheelite from calcite and fluorite using a collector mixture. Miner. Eng. 2015, 72, 23-26. [CrossRef]

34. Gao, Y.; Gao, Z.; Sun, W.; Hu, Y. Selective flotation of scheelite from calcite: A novel reagent scheme. Int. J. Miner. Process. 2015, 154, 10-15. [CrossRef]

35. Gao, Z.; Sun, W.; Hu, Y. New insights into the dodecylamine adsorption on scheelite and calcite: An adsorption model. Miner. Eng. 2015, 79, 54-61. [CrossRef]

36. Wang, D.Z.; Hu, Y.H. Solution Chemistry of Flotation; Hunan Science and Technology Press: Changsha, China, 1987; pp. 35-44.

37. Rao, J. Study on flotation behavior of bastnaesite. Master's Thesis, Central South University, Changsha, China, 2013.

(C) 2020 by the authors. Licensee MDPI, Basel, Switzerland. This article is an open access article distributed under the terms and conditions of the Creative Commons Attribution (CC BY) license (http://creativecommons.org/licenses/by/4.0/). 